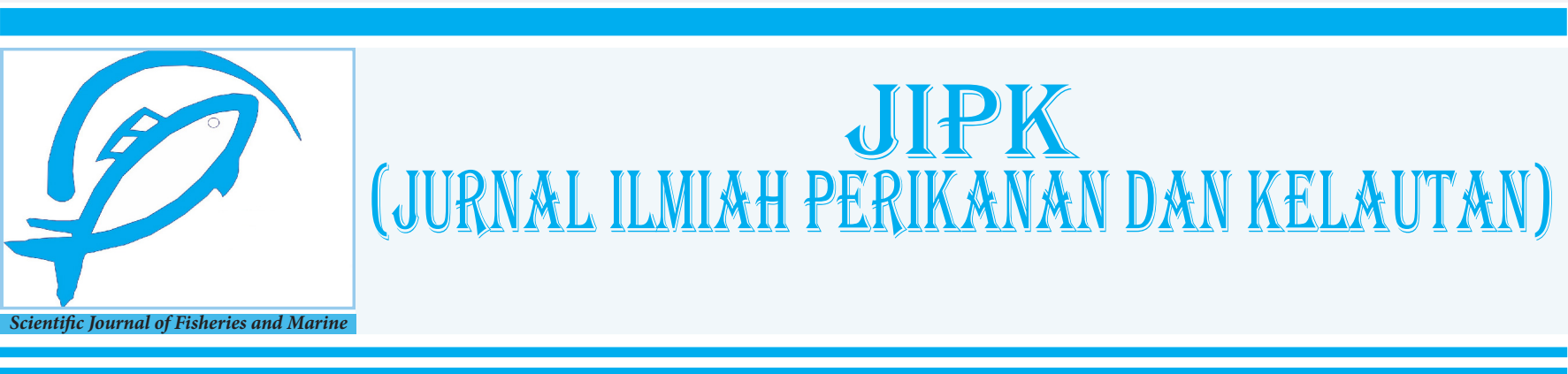

Research Article

\title{
Evaluating Marine Debris Trends and the Potential of Incineration in the Context of the COVID-19 Pandemic in Southern Bali, Indonesia
}

\author{
I Wayan Koko Suryawan ${ }^{1,2 *}$ (D), Ariyanti Sarwono ${ }^{1}$, Iva Yenis Septiariva ${ }^{3}$, and Chun-Hung Lee ${ }^{2}$ \\ ${ }^{1}$ Department of Environmental Engineering, Faculty of Infrastructure Planning, Universitas Pertamina, Jakarta, 12220. \\ Indonesia \\ ${ }^{2}$ Department of Natural Resources and Environmental Studies, National Dong Hwa University, Hualien, 97401. Taiwan \\ ${ }^{3}$ Department of Civil Engineering, Faculty of Engineering, Universitas Sebelas Maret, Surakarta, 57126. Indonesia
}

\section{OPEN ACCESS}

\section{ARTICLE INFO}

Received: February 01, 2021

Accepted: May 28, 2021

Published: September 28, 2021

*) Corresponding author:

E-mail: i.suryawan@universitaspertamina.ac.id

Keywords:

Marine Debris

Covid-19

Water content

Caloric value

Incineration

Plastic

Waste

This is an open access article under the CC BY-NC-SA license (https://creativecommons.org/ licenses/by-nc-sa/4.0/)

\begin{abstract}
Marine debris, a global environmental issue today, is a major threat to Bali seas which are famous for its natural beauty and aggravated by the spread of COVID-19 pandemic. This study aimed to determine the characteristics of marine debris in Bali Island, especially in the southern region and to analyze the feasibility of incineration as one of the waste treatment processes. This research was conducted by utilizing secondary data and literature reviews from related previous studies. Water content and caloric value were measured directly using the ASTM E 790-15 and ASTM D 5865-11a standards. Marine debris generation from 2013 to 2019 tends to decrease from $1.22 \mathrm{~kg} / \mathrm{km}$.day to $0.46 \mathrm{~kg} / \mathrm{km}$.day. Organic waste $(59.4 \%)$ comprised the largest marine debris followed by plastic waste (13.4\%) and diapers $(11.9 \%)$. Thermal technology such as incineration can be introduced to treat marine debris. The standard application of incinerator technology is moisture content and caloric value. The water content of marine debris is reportedly $54.56 \%$, therefore, further preliminary processing is needed, especially for waste with high moisture content, such as diapers and organic waste. The potential calorific value of marine debris during the COVID-19 pandemic obtained from calculating the total waste was $12.05 \mathrm{MJ} / \mathrm{kg}$ which still did not meet the incinerator application's standard criteria.
\end{abstract}

Cite this as: Suryawan, I. W. K., Sarwono, A., Septiariva, I. Y., \& Lee, C. H. (2021). Evaluating Marine Debris Trends and the Potential of Incineration in the Context of the COVID-19 Pandemic in Southern Bali, Indonesia. Jurnal Ilmiah Perikanan dan Kelautan,13(2):190-198. http://doi.org/10.20473/jipk.v13i2.25164 


\section{Introduction}

Bali Island is one of the most iconic tourism site globally, one of which provides marine tourism. The island is the centre of economic growth in which hotels, restaurants, and various trade and business facilities are world-class. One of the impacts is the increase of marine debris that will consequently deteriorate seawater quality. The seawater quality at several points in Bali Island does not meet quality standard, which is caused by poor waste management around the coastal area (Putra and Husrin, 2017; Septiariva and Suryawan, 2021). The effects of poor waste management on humans, wildlife, and the environment.

The sea contains a diversity of various biological resources whose survival is primarily determined by water quality conditions. The ocean also provides environmental services, a tourist attraction whose value depends on water quality. Seawater quality can be assessed by organic parameters such as organic hydrophobics (Bakir et al., 2016; Endo and Koelmans, 2016) as well as non-hydrophobic ones. Organic hydrophobics such as plastic bags, polyethylene terephthalate (PET) bottles, plastic cups, and styrofoam are huge seawater problems (Roman et al., 2020). Aside from plastic's durability and persistence, plastic production continues to increase while the recovery rate is low. This causes the accumulation of plastic debris along the coastline, on the surface of the water, at various depths of water, and in sediments (Barnes et al., 2009).

Overall, natural resources and marine environmental services have enormous potential to contribute to current and future development. The sea, which is a natural resource, needs to be protected by controlling pollution as part of environmental management. The transition between land and sea in coastal areas has formed diverse and highly productive ecosystems that provide tremendous economic value for society. One example of the impacts is that it can enter the digestive tract of organisms and increase the mortality rate of organisms living in rivers (Vermaire et al., 2017). In the ocean, plastic polymers are less biodegradable but are broken down into smaller pieces due to UV radiation and water currents. During COVID-19, an emerging problem that needs to be addressed today is the use of plastic-made personal protective equipment (PPE) such as N95 masks and face shields.

Improperly disposed PPE such as N95 masks has reportedly produced marine debris (Vanapalli et al., 2021). The N95 mask consists of a layer derived from polypropylene on the outer layer and charged polypropylene on the middle layer. This hazardous waste can be treated with incinerator technology to eliminate infectious properties. According to the Head of the Center for Education and Training for Roads, Housing, Settlements, and Regional Infrastructure Development in Indonesia, the criteria for minimum calorific value in waste is $7 \mathrm{MJ} / \mathrm{kg}$, and moisture content is below $50 \%$ (BPSDM, 2019). If the caloric value of the waste is less than $7 \mathrm{MJ} / \mathrm{kg}$, then pre-treatment or additional fuel is needed so that the caloric value is increased, and the incineration process can continue. Waste is categorized as capable of being incinerated without using auxiliary fuel if the waste has an ash content below $60 \%$ and a moisture content below 50\%. The operational requirements required if the raw material is outside this limit is the need for an air pre-heater if the calorific value of the raw material is low and the reserve steam capacity if the heating value exceeds the heating value.

This research examines the potential application of incineration in marine debris based on the characteristic of waste in several coastlines of Bali Island. The theoretical calculation of the moisture content and calorific value for marine debris was also carried out.

\section{Materials and Methods}

\subsection{Waste Generation and Composition}

The waste generation and composition samples were collected using primary and secondary data from various observation and sources. The estimation of waste generation was carried out based on an inventory by the Regional Corporate Affairs Manager of Coca Cola Amatil East Indonesia from 2013-2019. For ease of presentation, the waste generation data were then converted to tones $/ \mathrm{km}$.day using equation 1 . The study locations in this research are Jimbaran, Kedonganan, Legian, Kuta, and Seminyak. The above locations were selected because they are considered as the most extensive beaches in Bali (Yusdantara and Rahanatha, 2015). The secondary data were then analyzed using statistical means to see the trend of waste generation during the COVID-19 pandemic.

\section{Coastline waste generation (ton $/ \mathrm{km}$.day) $=$}

waste generation (ton/day)/ coastline length $(\mathrm{km})$......(1)

\subsection{Waste Characterization}

Waste characterization data is collected by taking proportional random sampling in Jimbaran, Kedonganan, Legian, Kuta, and Seminyak. Each waste with the same component was collected and then homogenized through a shredding machine and hammer mill. The type of waste collected was based on 
JIPK. Volume 13 No 2. November 2021 / Evaluating Marine Debris Trends and the Potential of Incineration in......

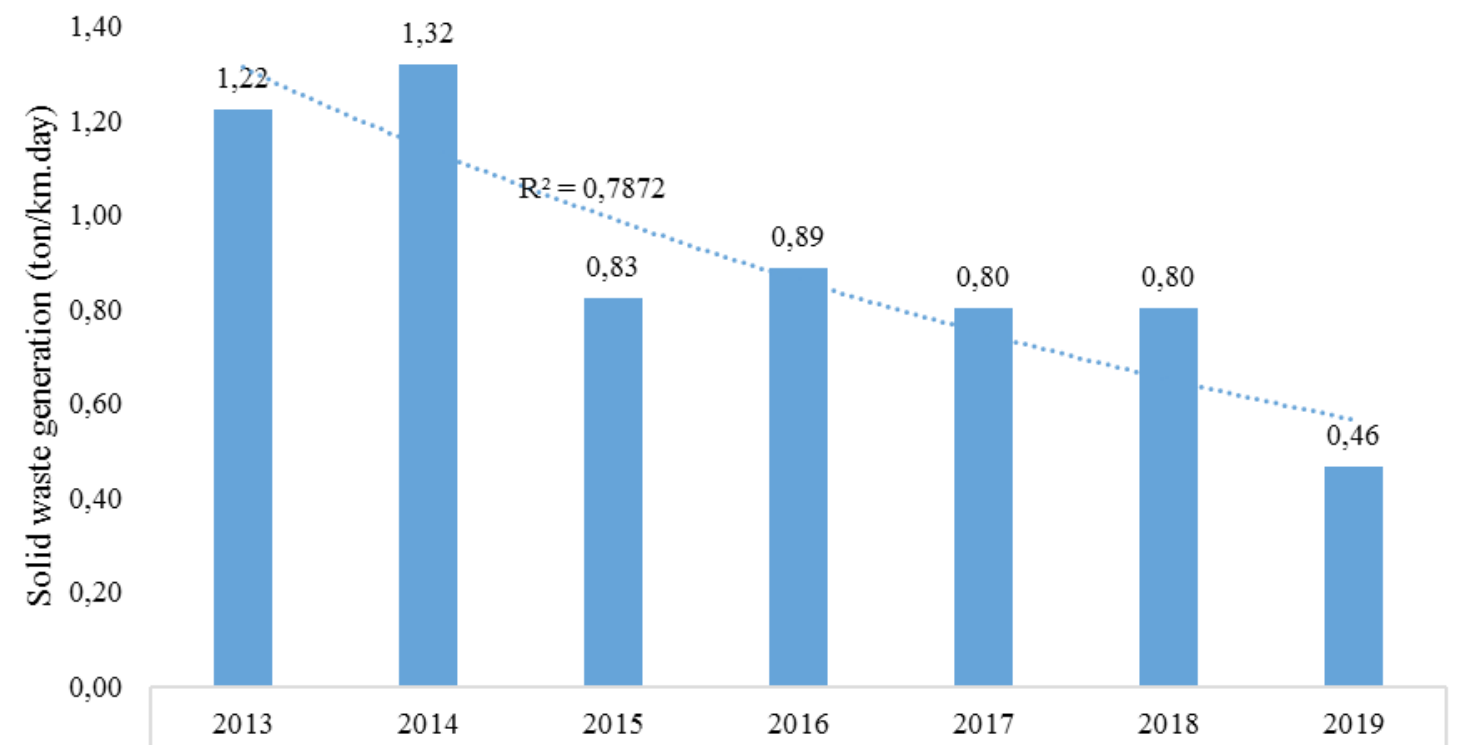

Figure 1. Marine debris generation from 2013 to 2019

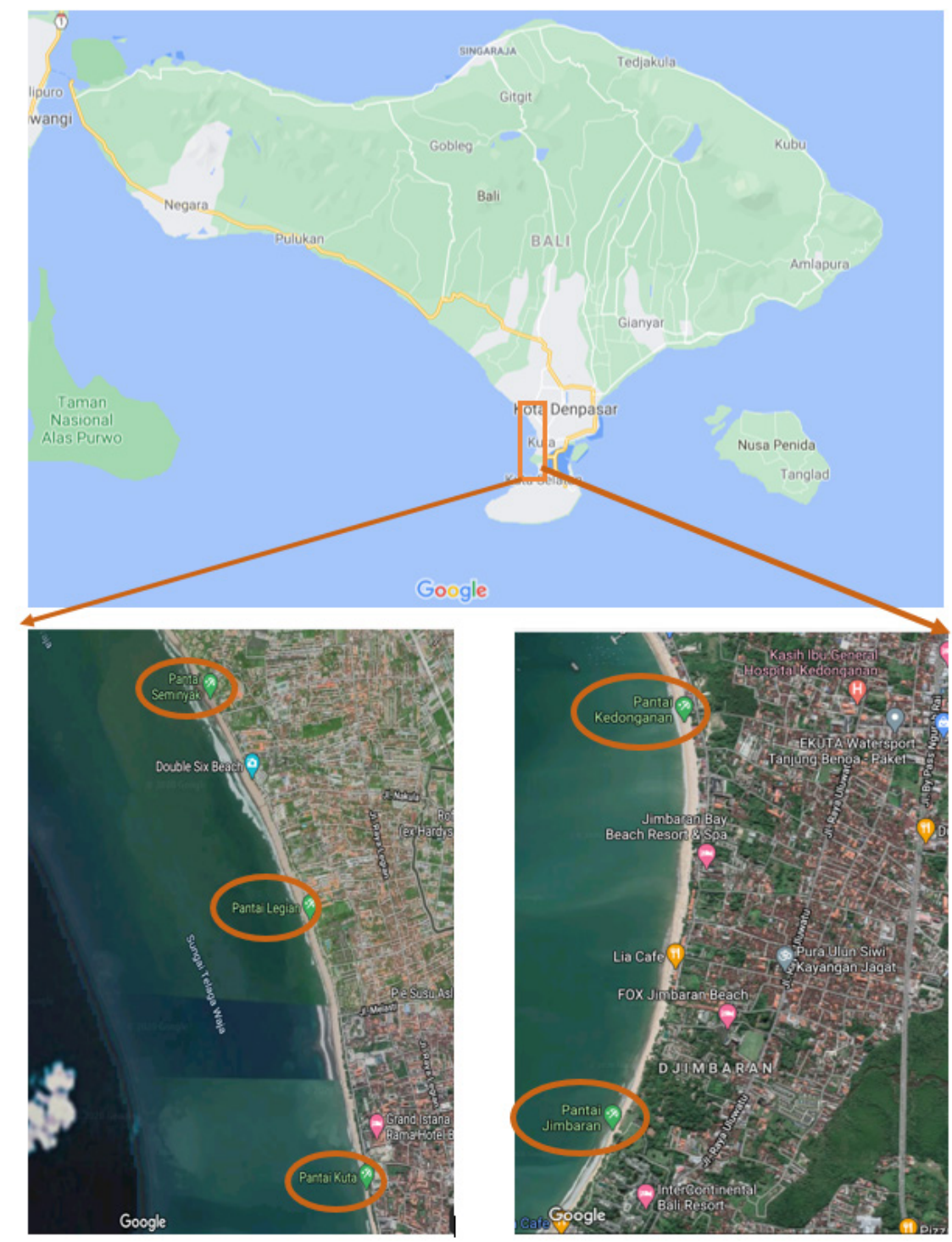

Figure 2. Location of the widest beach in the South Bali Region 
the composition of the World Bank (2018) study. The moisture content was measured by drying in an oven at $105^{\circ} \mathrm{C}$ until a constant weight had been achieved (Novita and Damanhuri, 2009). A bomb calorimeter each was experimentally determined using calorific value. Measurement of moisture content and caloric value referred to the ASTM E 790-15 and ASTM D 5865-11a standards.

Table 1. Results of measurements and calculations of marine debris water content

\begin{tabular}{lccc}
\hline \multicolumn{1}{c}{ Component } & \multicolumn{1}{c}{ Component Water content (\%) } & Dry weight (kg) & Wet weight (kg) Water content (\%) \\
\hline Diaper & $75,94 \%$ & 129,1 & 407,5 \\
Glass, metal, inert ma- & $0 \%$ & 207,4 & 0 \\
terial & $0,90 \%$ & 53,6 & 0,5 \\
Plastic bottles & $0 \%$ & 40,6 & 0 \\
Plastic cups & $8,60 \%$ & 552,3 & 52 \\
Plastic bags & $21,60 \%$ & 251 & 64.56 \\
Plastic packaging & $23,50 \%$ & 51,7 & 15,9 \\
Other plastics & $71,52 \%$ & 763,2 & 1915,5 \\
Other Organics &
\end{tabular}

Table 2. Measurement results and calculation of the calorific value of marine debris

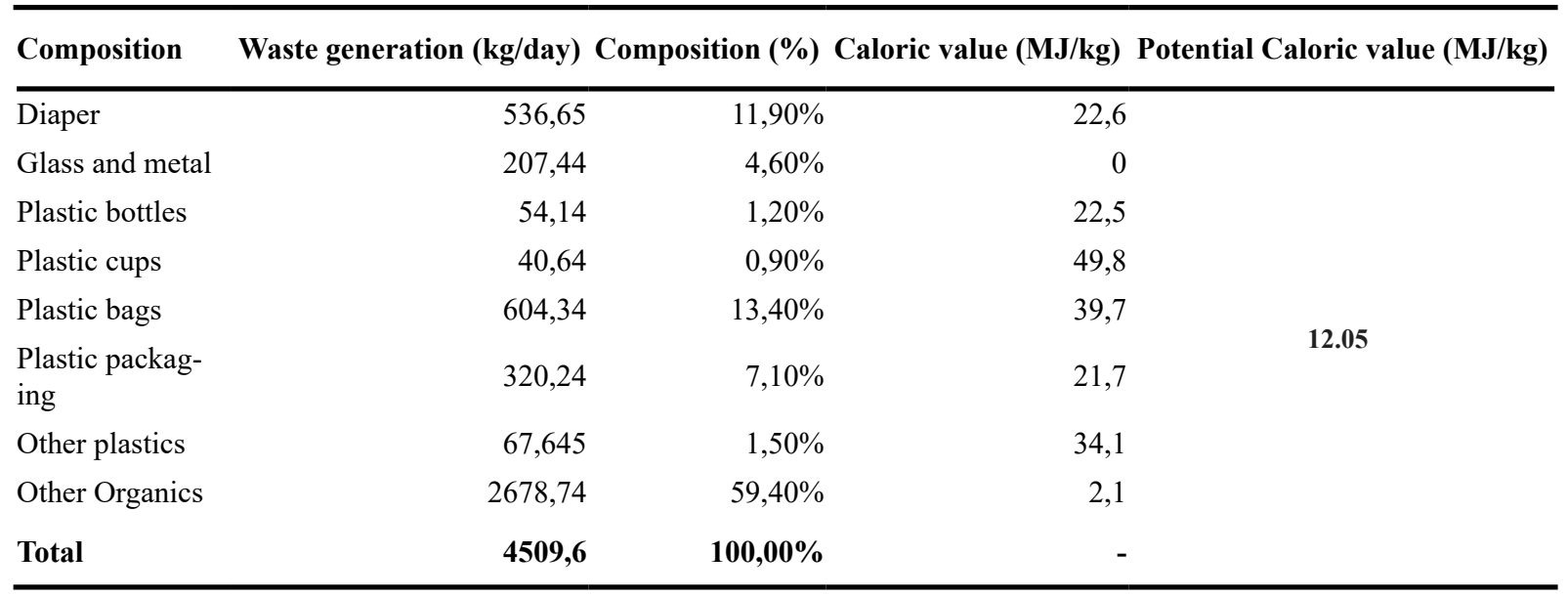
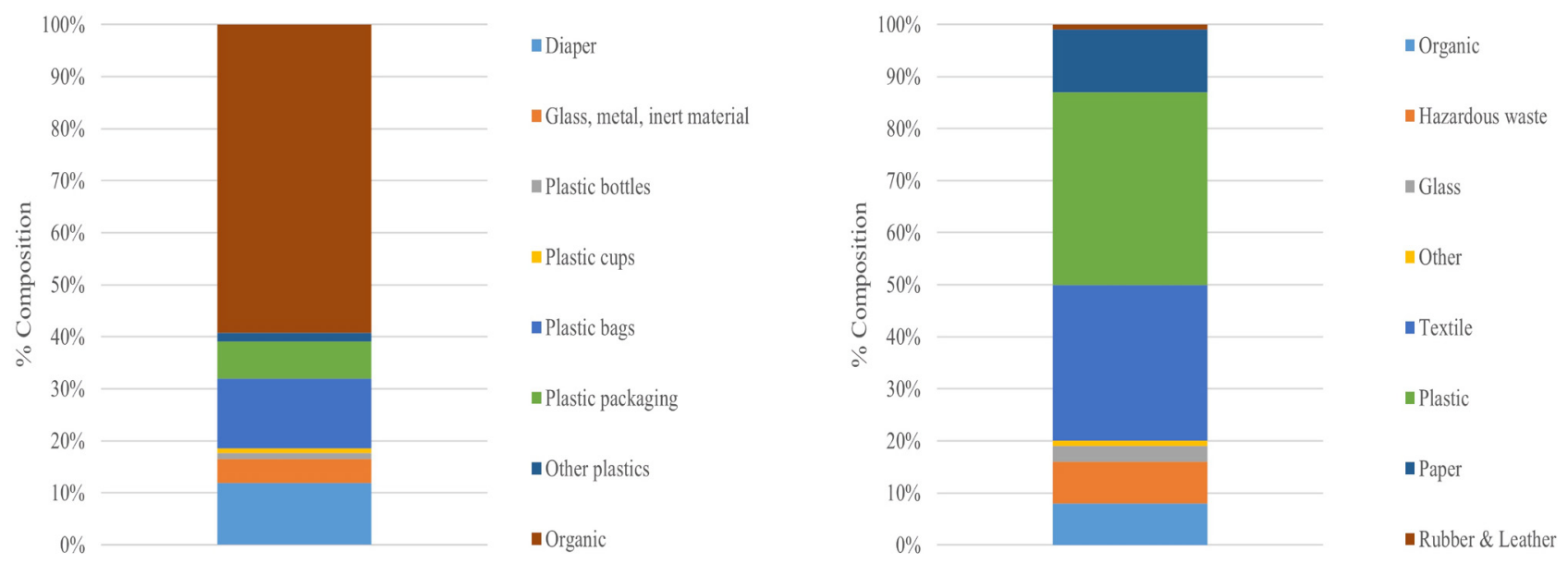

Figure 3. Composition of Marine Debris in Denpasar City (a) World Bank Data (World Bank, 2018) (b) Widyarsana et al. (Widyarsana et al., 2020) 


\subsection{Potential of Incineration Technology}

Potential measurements were carried out to determine the percentage of water content and the amount of energy possessed from the thermal incineration process. Water content and caloric value were then calculated using equation 2 and equation 3 respectively (Tchobanoglous et al., 1993). The calculation of water content and caloric value were then compared with standard incineration in Indonesia. The standard for water content is below $50 \%$ and the calorific value is higher than $7 \mathrm{MJ} / \mathrm{kg}$ (BPSDM, 2019).

Water content $(\%)=$

$\sum$ (water content waste component (\%) x waste generation component $(\mathrm{kg} /$ day $)$ / total waste generation $(\mathrm{kg} /$ day $)$

Caloric value $(\mathrm{MJ} / \mathrm{kg})=$

$\sum$ (caloric value waste component (\%) $\mathrm{x}$ waste generation component ( $\mathrm{kg} /$ day) / total waste generation $(\mathrm{kg} /$ day $)$.

\section{Results and Discussion}

\subsection{The Emergence of Marine Debris in the Southern Region of Bali Island}

The seasonal waste generation in the southern coastal area of Bali Island has decreased through 2013 to 2019. Waste generation value on the coast is obtained from processed data from Tribun News (Tribun News, 2019) (Figure 1). The reported study areas are Jimbaran, Kedonganan, Legian, Kuta, and Seminyak (Figure 2). The length of the coastline of the area is $9.7 \mathrm{~km}$. The five beaches mentioned above are the most extensive beaches on the island of Bali (Lasaliesanti, 2019). Yusdantara and Rahanatha (2015) stated that since 2008 to 2015, 21 million $\mathrm{kg}$ of waste was generated. The waste could reach 4 tons/day at Gili Terawangan, 1-2 tons/day at Gili Meno, 2 tons/day at Gili Air, while during year-end holidays it peaked to 14 tons/day at Gili Terawangan (Darwati, 2019). This shows that the waste in coastal areas can increase by about four times the usual quantity during holidays. Apart from holidays, more trashes were sent to those five beaches during the rainy season (Lasaliesanti, 2019).

Marine debris generation results from ineffective collection and transportation patterns along the coastline. This condition because marine debris is affected by the tides; at low tide, the marine debris gets trapped on land and during high tide, the waste is carried along with the currents of the ocean waves. Not all waste is carried away; some waste settles and remains on the beach sand (Enggara et al., 2019). Opfer et al. (2012) stated that the high and low water levels (tides) affect the volume/amount of waste in a coastal area.

Indonesia is the world's second-largest contributor to plastic waste to the ocean after China, with an estimated 0.48-1.29 million metric tons per year (Jambeck, et al., 2015). According to Barboza et al., (2019), global marine debris will keep increasing in 2025. In contrast to the above reported prediction, the measurement results of waste generation from year to year tend to decline. The government issued the Governor of Bali Regulation No.97/2018 concerning the Limitation of Single-Use Plastic Waste Generation (Governor of Bali, 2018). This is to protect the marine ecosystem; in general, the plastic waste that possibly enters the sea through existing rivers was predominantly caused by anthropogenic activities on land (Lebreton et al., 2017).

\subsection{Composition of Marine Debris in the Southern Region of Bali Island}

A study by Jambeck et al. (2015) assumes that the composition of plastic waste in Indonesia is $11 \%$, while the World Bank, (2018) estimates that the percentage of plastic waste in East Asia and the Pacific region is $13 \%$ and $12 \%$ in Indonesia. An interesting finding from the World Bank (World Bank, 2018) is the significant incidence of disposable diapers in the waste samples taken. On average, $11.9 \%$ of the waste consists of disposable diapers. Although disposable diapers are not classified as plastic in the World Bank study (Figure 3), they contain plastic components such as styrofoam. Styrofoam waste is often digested by birds, turtles, whales, and other marine animals, and adversely impacts these marine animals (Katsanevakis, 2008).

During the COVID-19 pandemic, various preventive efforts were taken to avoid contracting the COVID-19 virus. As an individual preventive measure, PPE use such as masks for health workers is echoed massively. The disposal of PPE leads to a higher number of medical waste and detrimentally impacts the environment. Unfortunately, Indonesia still has limited medical waste treatment services. In the end, many medical wastes frequently end up in rivers, or even worse, at sea. Recent reports from Republika (2020) stated that during the Covid-19 pandemic, the composition of waste has shifted to face masks and face shields.

The Ministry of National Development Planning/Bappenas had previously prepared a plan for implementing SDGs from 2020 to 2030. However, the COVID-19 pandemic urged Bappenas to formulate 
a new strategy for implementing SDGs in Indonesia (Kompas, 2020). Social restrictions and lockdown policies in several countries have helped to conserve flora and fauna biodiversity. Reported marine debris types during the COVID-19 pandemic are disposable masks, plastic gloves, personal protective clothing, and plastic food packaging (Farhani, 2020). In Jakarta, PPE waste generation reaches $15-16 \%$ of the collected river debris (Cordova et al., 2021), this indicates a change in the composition of waste generation during and before the pandemic. Similar to Jakarta, the generation of urban waste in Bali Province has also experienced changes in characteristics during the COVID-19 pandemic (Suryawan et al., 2021). These findings tend to change the characteristics of waste due to limited community activities, especially tourism activities in Bali Province. The opening of tourism must also support good management updates. Our findings show that some communities disposed of medical mask waste during the pandemic (Figure 4). The support for sustainable tourism and environment must carry out further management and policies for this medical mask. Medical mask waste is classified as Polypropylene plastic waste (Jain et al., 2020). Previously, Widyarsana et al. (2020) stated that plastic waste is the dominant waste, hence the emergence of mask waste will reintroduce the increasingly complex problem of plastic waste.

\subsection{Marine Debris Reduction Policy}

The selection of thermal technology for marine debris is currently linked to several related regulations, namely the Minister of Public Works Regulation No. 03/PRT/M/2013 concerning the Implementation of Infrastructure and Facilities for Handling Household Waste and Household-like Waste (Menteri Pekerjaan Umum RI, 2013) and Circular of the Minister of Environment No. SE.2/MENLHK/PSLB3/ PLB.3/3/2020 concerning Management of Infectious
Waste (B3) and Household Waste from Handling Corona Virus Disease (COVID-19) (Menteri Lingkungan Hidup, 2020). The alternative waste management currently being researched and developed is converting plastic waste into fuels. The prevention of infectious waste and marine debris treatment, waste processing can be carried out using an incinerator. The parameters reviewed are based on the Head of the Center for Education and Training for Roads, Housing, Settlements, and Indonesian Regional Infrastructure Development. The minimum calorific value requirement in waste is 7 $\mathrm{MJ} / \mathrm{kg}$, and the water content is below $50 \%$ (BPSDM, 2019).

Diapers waste has the highest water content, which reaches $75.94 \%$ and is followed by an organic waste of $71.52 \%$. Organic marine debris is based on seaweed waste, microalgae, leaves, wood, and twigs. During the pandemic on March 18, 2020, around 10 tons of seaweed debris were found on the shoreline along 250 meters (Nusa Bali, 2020). In processing marine debris, especially diapers and organics, the water content must be taken into consideration to meet the standard (BPSDM, 2019). The estimation of the theoretical value of wastewater is calculated where plastic waste is seen including waste that represents the composition of marine debris (Table 1). Furthermore, Polypropylene medical masks are also included in other waste categories having a water content of $23.5 \%$ which affects the calorific value.

The calorific value of glass and metal is not considered due to their high ash content. The overall calorific value of marine debris can attain $12.05 \mathrm{MJ} /$ $\mathrm{kg}$ (Table 2). Based on prior research, plastic waste management of converting into oil on Kuta Beach Bali could obtain a calorific value of $41.86 \mathrm{MJ} / \mathrm{kg}$ (Wedayani, 2018). In addition, due to its low water content, PPE plastic could provide a high calorific value (Jain et al., 2020). Overall, the plastic waste
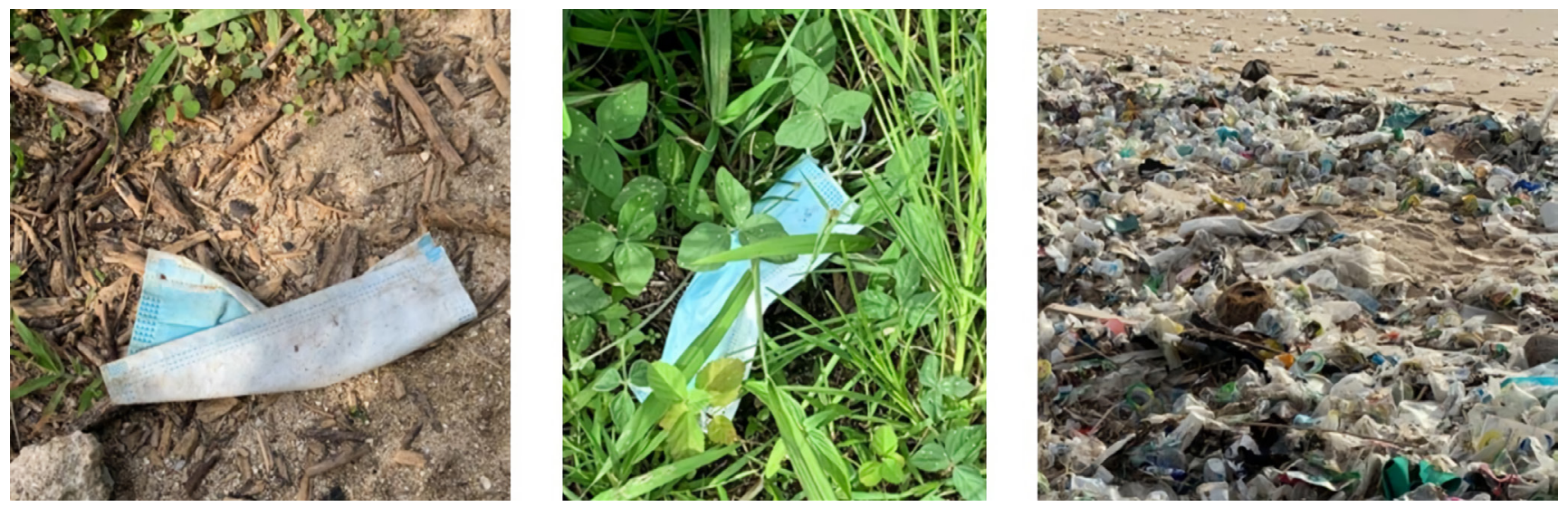

Figure 4. Observations of PPE and Plastic Waste Debris Findings on Southern Bali 
JIPK. Volume 13 No 2. November 2021 / Evaluating Marine Debris Trends and the Potential of Incineration in......

present can be potentially converted to optimum energy. Although thermal waste processing can cause air emissions, it can be monitored through air pollution control. One effort that can be made is water filtration (Subekti et al., 2020). Destroying marine debris with thermal processing will become a consideration in choosing policies by the government. The management of marine debris during COVID-19 is one way to support sustainable development, especially for clean energy and to save underwater life. Properly processed and controlled PPE COVID-19 waste does not interfere with aquatic life. PPE waste which is a new category will increase the amount of marine debris. The increasing amount of marine debris will have an impact on the life of coral reefs (Putra et al., 2021).

\section{Conclusion}

Marine debris generation from 2013 to 2019 decreased from $1.22 \mathrm{~kg} / \mathrm{km}$.day to $0.46 \mathrm{~kg} / \mathrm{km}$. day respectively, with an organic waste composition of $59.4 \%$ at 2019 . The water content of $54.56 \%$ exceeds the maximum standard, therefore, the use of an incinerator may not be directly suitable for marine debris. However, the pre-treatment could be performed for marine debris with high water content, such as organic and diapers. The existence of mask waste made of polypropylene plastic can change marine debris characteristics during the COVID-19 pandemic. The PPE plastic waste must be managed properly so that it does not add to aquatic life, one of which is through thermal processing. The overall calorific value complies during the COVID-19 pandemic with the standard incineration value of 12.05 $\mathrm{MJ} / \mathrm{kg}$.

\section{Acknowledgement}

The authors would like to thank you to the LPPMI Universitas Pertamina and reviewers of constructive and competent criticism for this research.

\section{Author's Contribution}

The authors confirm contribution to the paper and responsibility for study conception and design, data collection, literature review, analysis of results, and manuscript preparation.

\section{Conflict of Interest}

The author declares that the research was undertaken in the absence of any commercial or financial relationships that could be construed as a potential conflict of interest.

\section{Funding Information}

The authors did not receive financial support from any organization for this research.

\section{References}

Bakir, A., O'Connor, I. A., Rowland, S. J., Hendriks, A. J., \& Thompson, R. C. (2016). Relative importance of microplastics as a pathway for the transfer of hydrophobic organic chemicals to marine life. Environmental Pollution, 219:56-65.

Barboza, L. G., Cózar, A., Gimenez, B. C., Barros, T. L., Kershaw, P. J., \& Guilhermino, L. (2019). Macroplastics pollution in the marine environment. In C. Sheppard (Ed.), World seas: An environmental evaluation. (pp. 329-351). Cambridge MA: Academic Press.

Barnes, D. K., Galgani, F., Thompson, R. C., \& Barlaz, M. (2009). Accumulation and fragmentation of plastic debris in global environments. Philosophical Transactions of the Royal Society B: Biological Sciences, 364(1526):1985-1998.

BPSDM. (2019, April). Modul Pelatihan Teknologi WtE Termal Insinerasi. Retrieved 09 12, 2020, from https://bpsdm.pu.go.id/center/pelatihan/uploads/ edok/2019/04/e34ac_9._Modul_Insinerasi.pdf

Cordova, M. R., Nurhati, I. S., Riani, E., \& Iswari, M. Y. (2021). Unprecedented plastic-made personal protective equipment (PPE) debris in river outlets into Jakarta Bay during COVID-19 pandemic. Chemosphere, 268:129360.

Darwati, S. (2019). Pengelolaan sampah kawasan pantai. Seminar Nasional Pendidikan Biologi dan Saintek (SNPBS) ke-IV from https://publikasiilmiah.ums. ac.id/xmlui/handle/11617/11347

Endo, S., \& Koelmans, A. A. (2016). Sorption of hydrophobic organic compounds to plastics in the marine environment: equilibrium. In H. Takada, H.K. Karapanagioti (Eds.), Hazardous chemicals associated with plastics in the marine environment. (pp. 185-204). Springer International Publishing Switzerland.

Enggara, R., Bahrum, Z., \& Suherman, D. (2019). Kajian mekanisme penyebaran sampah di kawasan pantai pariwisata Kota Bengkulu sebagai penyebab degradasi nilai-nilai ekowisata. Naturalis: Jurnal Penelitian Pengelolaan Sumber Daya Alam dan 


\section{Lingkungan, 8(2):39-48}

Farhani, N. (2020). Pengendalian pencemaran dan kerusakan pesisir dan laut dari sampah masa pandemi Covid-19. Direktorat Pengendalian Pencemaran dan Kerusakan Pesisir Dan Laut, Direktorat Jenderal Pengendalian Pencemaran dan Kerusakan Lingkungan Kementerian Lingkungan Hidup dan Kehutanan Republik Indonesia. Retrieved from https://kkp.go.id/an-component/ media/upload-gambar-pendukung/DitJaskel/ publikasi-materi-2/dampak-pandemi-sampah-aut/ Novy\%20Farhani.pdf

Governor of Bali. (2018). Peraturan Gubernur Bali No.97/2018 tentang pembatasan timbulan sampah plastik sekali pakai. Bali.

Jain, S., Yadav Lamba, B., Kumar, S., \& Singh, D. (2020). Strategy for repurposing of disposed PPE kits by production of biofuel: Pressing priority amidst COVID-19 pandemic. Biofuels:1-5.

Jambeck, J. R., Geyer, R., Wilcox, C. S., Perryman, M., Andrady, A., \& Law, K. L. (2015). Plastic waste inputs from land into the ocean. Science, 347(6223):768-771.

Katsanevakis, S. (2008). Marine debris, a growing problem: sources, distribution, compotition, and impact. In Tobias N Hofer (Ed.), Marine Pollution: New Research (pp. 53-100). New York: Nova Science Publishers.

Kompas. (2020, Mei). Karena Covid-19, Bappenas lakukan penyesuaian draf pembangunan berkelanjutan. Retrieved from https://money. kompas.com/read/2020/05/15/134354126/karenacovid-19-bappenas-lakukan-penyesuaian-drafpembangunan-berkelanjutan

Lasaliesanti, P. (2019). Implementasi program Bali beach clean up sebagai corporate social responsibility (CSR) oleh perusahaan Coca-Cola Amatil Indonesia di Pantai Kuta Bali. Aspirasi: Jurnal Ilmiah Administrasi Negara, 4(1):5-8.

Lebreton, L., van der Zwet, J., Damsteeg, J., Slat, B., Andrady, A., \& Reisser, J. (2017). River plastic emissions to the World's Oceans. Nature Communications, (8)15611: 1-10.

Menteri Lingkungan Hidup. (2020). Surat Edaran Menteri Lingkungan HIdup No. SE.2/MENLHK/ PSLB3/PLB.3/3/2020 tentang pengelolaan limbah infeksius (B3) dan sampah rumah tangga dari penanganan Corona virus disease (Covid 19). Retrieved 09 2020, from https://www.mongabay. co.id/wp-content/uploads/2020/04/SE-MenteriLingkungan-Hidup-soal-Pengelolaan-LimbahInfeksius-dan-Sampah-Rumah-Tangga-dariPenangananan-Limbah-Virus-Corona.pdf

Menteri Pekerjaan Umum RI. (2013). Peraturan Menteri Pekerjaan Umum RI No. 03/PRT/M/2013 tentang penyelenggaraan prasarana dan sarana persampahan dalam penanganan sampah rumah tangga dan sampah sejenis sampah rumah tangga. Jakarta.

Novita, D. M., \& Damanhuri, E. (2009). Caloric valuebased on composition and characteristics of municipal solid waste in indonesia in waste to energy concept. Jurnal Teknik Lingkungan, 16(2):103-114.

Nusa Bali. (2020, Maret). Sampah rumput laut berdatangan di Pantai Nusa Dua. Retrieved 09 12, 2020, from https://www.nusabali.com/ berita/70551/sampah-rumput-laut-berdatangan-dipantai-nusa-dua

Opfer, S., Arthur, C., \& Lippiatt, S. (2012). NOAA Marine Debris Shoreline Survey Field. 449.

Putra, A., \& Husrin, S. (2017). Water quality of post contamination of marine debris in the Kuta beach of Bali. Jurnal Ilmu dan Teknologi Kelautan Tropis, 9(1):57-66.

Putra, M. G. A., Zamani, N. P., Natih, N. M., \& Harahap, S. A. (2021). Relationship between characteristics of marine debris and impact to coral reef. Jurnal Ilmiah Perikanan dan Kelautan, 13(1):11-19.

Republika. (2020). Ketika laut jakarta dipenuhi sampah APD. Retrieved 09 10, 2020, from https:// republika.co.id/berita/qc4ibo328/ketika-lautjakarta-dipenuhi-sampah-apd

Roman, L., Hardesty, B. D., Leonard, G. H., PragnellRaasch, H., Mallos, N., Campbell, I., \& Wilcox, C. (2020). A global assessment of the relationship between anthropogenic debris on land and the seafloor. Environmental Pollution, 264(114663).

Septiariva, I. Y, \& Suryawan, I. W. K. (2021). Development of water quality index (WQI) and hydrogen sulfide $\left(\mathrm{H}_{2} \mathrm{~S}\right)$ for assessment around suwung landfill, Bali Island. Journal of Sustainability Science And Management, 16(4).

Subekti, S., Basuki, P., \& Purwaningrum, S. D. (2020). 
Pembakar sampah rendah emisi dengan air sebagai filtrasi. Neo Teknika, 6(2):6-11.

Suryawan, I. W. K., Rahman, A., Septiariva, I. Y., Suhardono, S., \& Wijaya, I. M. W. (2021). Life cycle assessment of solid waste generation during and before pandemic of Covid-19 in Bali Province. Journal of Sustainability Science And Management, 16(1):11-21. h

Tchobanoglous, G., Theisen, H., \& Vigil, S. (1993). Integrated solid waste management: Engineering principles and management issues. New York: McGraw-Hill.

Tribun News. (2019). Sampai Juni Sudah 1.646 Ton Sampah di Pesisir 5 Pantai Favorit Bali ini.

Vanapalli, K. R., Sharma, H. B., Ranjan, V. P., Samal, B., Bhattacharya, J., \& Dubey, B. K. (2021). Challenges and strategies for effective plastic waste management during and post COVID-19 pandemic. Science of The Total Environment, 750:141514.

Vermaire, J. C., Pomeroy, C., Herczegh, S. M., Haggart,
O., \& Murphy, M. (2017). Microplastic abundance and distribution in the open water and sediment of the Ottawa River, Canada, and its tributaries. Facets, 2(1):301-314.

Wedayani, N. M. (2018). Studi pengelolaan sampah plastik di Pantai Kuta sebagai bahan bakar minyak. Jurnal Presipitasi: Media Komunikasi dan Pengembangan Teknik Lingkungan, 15(2):122126.

Widyarsana, I. M., Damanhuri, E., Ulhusna, N., \& Agustina, E. (2020). A Preliminary study: identification of stream waste quantity and composition in Bali Province, Indonesia. E3S Web of Conferences, 148, 05005.

World Bank. (2018). Hotspot sampah laut Indonesia. Jakarta: World Bank.

Yusdantara, I. K., \& Rahanatha, G. B. (2015). Pengaruh corporate social responsibility terhadap reputasi perusahaan yang dimediasi oleh kepuasan pelanggan (studi pada PT. Coca Cola Amatil Denpasar). E-Jurnal Manajemen Unud, 4(4): 813- 